\title{
Pengembangan Model Layanan Pendidikan Creative Art Play Therapy bagi Anak Berkebutuhan Khusus
}

\author{
Sayni Nasrah*1, Siraj $^{2}$, Dahrum $^{3}$ \\ ${ }^{* 1}$ Program Studi Pendidikan Bahasa Indonesia, ${ }^{2}$ Program Studi Pendidikan Vokasional \\ Teknik Mesin, ${ }^{3}$ Program Studi Pendidikan Bahasa Indonesia, \\ FKIP Universitas Malikussaleh \\ *Corresponding Author. Email: sayni.nasrah@unimal.ac.id
}

\begin{abstract}
This study aims to design a model of creative art play therapy education services to overcome various basic problems in providing friendly services for children with special needs (ABK) at Azura Sejati Inklusif PAUD Lhokseumawe. This study uses the Research and Development Borg and Gall method. The subjects in this study were teachers at the Azura Sejati Inklusif PAUD Lhokseumawe. The data used are qualitative and quantitative data, with data collection techniques through observation, interviews, documentation, questionnaires, and Focus Group Discussions (FGD). The data analysis technique used descriptive statistical analysis and inferential statistics. The results showed that the creative art play therapy educational service model was effectively used to provide friendly services for children with special needs (ABK) in dealing with social problems and self-control. All creative art play processes (1) creative visualization can stimulate children's understanding and thought processes; (2) storytelling activities can develop moral and spiritual; (3) drama can improve social relations, hand puppets and masks have been used to protect themselves; (4) art to develop creativity and aesthetic experience; (5) music to communicate; (6) dance and movement to develop physical motor skills.
\end{abstract}

\begin{abstract}
Abstrak: Penelitian ini bertujuan untuk merancang model layanan pendidikan creative art play therapy untuk mengatasi berbagai permasalahan yang mendasar dalam memberikan pelayanan ramah anak berkebutuhan khusus (ABK) di PAUD Azura Sejati Inklusif Lhokseumawe. Penelitian ini menggunakan metode Research and Development Borg dan Gall. Subjek dalam penelitian ini adalah guru di PAUD Azura Sejati Inklusif Lhokseumawe. Data yang digunakan adalah data kualitatif dan kuantitatif, dengan teknik pengumpulan data melalui observasi, wawancara, dokumentasi, angket, dan Focus Group Discussion (FGD). Teknik analisis data menggunakan analisis statistik deskriptif dan statistik inferensial. Hasil penelitian menunjukkan bahwa model layanan pendidikan creative art play therapy efektif digunakan untuk memberikan pelayanan ramah anak berkebutuhan khusus (ABK) dalam menghadapi masalah sosial dan pengendalian diri. Semua proses bermain creative art (1) visualisasi kreatif dapat menstimulasi pemahaman dan proses berpikir anak; (2) kegiatan bercerita dapat mengembangkan moral dan spiritual; (3) drama mampu meningkatkan hubungan sosial, boneka tangan dan topeng telah digunakan digunakan untuk melindungi diri; (4) seni untuk mengembangkan kreativitas dan pengalaman estetis; (5) musik untuk berkomunikasi; (6) tari dan gerak untuk mengembangkan fisik motorik.
\end{abstract}

\section{Article History}

Received: 10-11-2021

Revised: $17-12-2021$

Accepted: 23-12-2021

Published: 07-01-2022

\section{Key Words:}

Creative Art, Play

Therapy, Children with Special Needs.

\section{Sejarah Artikel}

Diterima: 10-11-2021

Direvisi: 17-12-2021

Disetujui: 23-12-2021

Diterbitkan: 07-01-2022

\section{Kata Kunci: \\ Creative Art, Play \\ Therapy, ABK.}

How to Cite: Nasrah, S., Siraj, S., \& Dahrum, D. (2022). Pengembangan Model Layanan Pendidikan Creative Art Play Therapy bagi Anak Berkebutuhan Khusus. Jurnal Paedagogy, 9(1), 1-7. doi:https://doi.org/10.33394/jp.v9i1.4547 


\section{Pendahuluan}

Setiap manusia memiliki hak yang sama dalam memperoleh pendidikan yang layak, adil, bermutu, tidak diskriminasi dan terbuka bagi semua individu dalam mengakomodasi semua kebutuhan sesuai dengan kondisi individu. Sistem layanan pendidikan tersebut adalah pendidikan inklusif, yang memberikan kesempatan kepada semua anak untuk belajar bersama di sekolah umum dengan memperhatikan keragaman dan kebutuhan individu agar potensi anak dapat berkembang secara optimal melalui pendidikan yang disebut ramah anak. Prinsip ramah anak ini merupakan layanan pendidikan yang memberikan hak kepada semua anak berkebutuhan khusus untuk belajar mengembangkan semua potensi yang dimilikinya pada lingkungan sekolah yang nyaman, aman dan terbuka. Penyelenggaraan pendidikan yang berkualitas untuk semua siswa dalam setting inklusif merupakan tantangan, kepentingan dan isu dalam pendidikan. Oleh karena itu, inklusifitas akan merupakan karakteristik dari sekolah di masa mendatang (Rudiyati, 2013).

Salah satu bentuk pengenalan bakat dan potensi yang dimiliki oleh ABK dapat dilihat melalui model creative art play therapy, sehingga anak berkembang secara holistik dari segi akademik, sosial, emosional, dan spiritual. Milfayetty (2017) mengemukakan bahwa salah satu cara untuk pengenalan bakat dan potensi yang dimiliki oleh ABK dapat dilakukan melalui model creative art. Konseling dengan creative art dilakukan dengan menggunakan berbagai media seni dan kreativitas di dalam prosesnya. Model creative art play therapy ditujukan untuk mengembangkan fisik motorik, kemampuan berkomunikasi, kemampuan memahami sesuatu, membina hubungan sosial, melatih emosi, moral dan spiritual, kreativitas dan melindungi diri sendiri secara simultan dan menyeluruh. Sesuai dengan konsep ini maka model ini menggunakan berbagai jenis bermain secara terpadu yang dapat dipadukan dengan kearifan lokal Aceh.

Berdasarkan penjelasan di atas, maka sangat penting terselenggaranya suatu layanan pendidikan sesuai dengan kebutuhan belajar masing-masing anak berkebutuhan khusus terutama pada tingkat pendidikan yang paling dasar, yaitu Pendidikan Anak Usia Dini (PAUD) dan Taman Kanak-kanak (TK). Ini merupakan titik sentral dan sangat fundamental mengingat bahwa anak usia dini merupakan masa keemasan, sekaligus periode yang sangat kritis dalam tahap perkembangan individu.

Pemerintah Kota Lhokseumawe memberikan perhatian tinggi terhadap pendidikan inklusif. Hal tersebut salah satunya didorong oleh meningkatnya kebutuhan akan adanya sebuah layanan pendidikan khusus yang bermutu. Hasil observasi di beberapa PAUD dan TK di Kota Lhokseumawe dan wawancara dengan ketua IGTKI dan guru PAUD Azura Sejati Inklusif Lhokseumawe ditemukan bahwa masih terdapat kendala-kendala dalam penyelenggaraan layanan pendidikan ramah bagi ABK. Kendala-kendala tersebut diantaranya adalah belum meratanya guru pembimbing khusus ABK di PAUD dan TK, kurangnya kompetensi guru dalam memberikan layanan yang maksimal bagi ABK, terbatasnya sarana dan prasarana ramah $\mathrm{ABK}$, dan rata-rata guru PAUD dan TK tidak paham bagaimana dalam mengoptimalkan potensi ABK dalam belajar dan berkembang.

Gagasan bahwa guru perlu merubah kelas dan lingkungan belajar agar semua anak bisa belajar, menjadi tuntutan di sekolah inklusif. Oleh karena itu, harapan bahwa guru akan melakukan apapun untuk menjamin bahwa setiap siswa akan belajar dengan baik. Perubahan praktek mengajar secara efektif menuntut inisiatif dan tanggung jawab tingkat tinggi. Para Guru membutuhkan keleluasaan waktu dan energi untuk mengejar pengembangan profesionalitas dan adaptasi praktik secara kontinu. Menurut Weiner (2003) guru perlu menumbuhkan hal-hal seperti: (1) belajar dari pengalaman secara terus-menerus; (2) 
melakukan refleksi; (3) melakukan teoritisasi tentang bagaimana yang terbaik untuk menemukan kebutuhan siswa, baik secara individual maupun secara kolektif; (4) belajar melalui kolaborasi dengan kolega secara terus menerus. Guru perlu melihat keragaman siswa sebagai tantangan yang dapat mereka hadapi secara sukses. Dengan dukungan, para guru dapat berusaha untuk melatih komitmen moral mereka untuk menangani semua siswa sebagai kecakapan untuk menemukan standar prestasi yang tinggi.

Berdasarkan hal tersebut, maka menjadi sangat penting untuk dilakukan pengembangan model layanan pendidikan menggunakan creative art play therapy berbasis kearifan lokal untuk meningkatkan perkembangan ABK. Mengingat keterbatasan waktu dan biaya, maka penelitian ini dilakukan pada PAUD Azura Sejati Inklusif Lhokseumawe. Hal ini juga sesuai dengan rekomendasi dari ketua Ikatan Guru Taman Kanak-kanak Indonesia (IGTKI) Kota Lhokseumawe IGTKI bahwa PAUD Azura Sejati Inklusif memiliki karakteristik sesuai dengan kebutuhan penelitian.

\section{Metode Penelitian}

Penelitian ini menggunakan metode Research and Development. Lokasi penelitian dilaksanakan di Kota Lhokseumawe Provinsi Aceh. Subjek dalam penelitian ini adalah kepala sekolah, guru, dan ABK di PAUD Azura Sejati Inklusif Lhokseumawe. Data yang digunakan adalah data kualitatif dan kuantitatif, dengan teknik pengumpulan data melalui observasi, wawancara, dokumentasi, angket, dan Focus Group Discussion (FGD). Penelitian ini dilaksanakan mulai 29 Juli s.d 23 November 2021.

Langkah selanjutnya adalah melakukan uji coba model layanan pendidikan creative art play therapy untuk meningkatkan perkembangan anak berkebutuhan khusus yang telah dibuat. Uji coba dilakukan sebanyak 3 kali, yaitu: uji-ahli, uji terbatas dilakukan terhadap kelompok kecil sebagai pengguna produk, dan uji-lapangan. Dengan uji coba model, diharapkan model yang dikembangkan betul-betul teruji secara empiris. Data yang telah terkumpul kemudian dilakukan pengujian oleh ahli yang berisi ketepatan substansi, ketepatan metode, dan ketepatan desain model yang telah dihasilkan. Analisis data penggunaan perhitungan dan analisis statistik sejalan model yang akan dikembangkan. Penyajian data hasil uji coba bersifat komunikatif, sehingga dalam mencerna informasi yang disajikan dapat menumbuhkan ketertarikan untuk menggunakan model hasil pengembangan. Simpulan yang ditarik dari hasil analisis data uji coba menjelaskan produk yang diujicobakan sebagai dasar pengambilan keputusan apakah model yang dihasilkan perlu direvisi atau tidak melalui pertimbangan ahli dua ahli pendidikan inklusif. Pertimbangan ahli dalam penelitian ini dilakukan melalui diskusi kelompok dan teknik delphi. Teknik analisis data menggunakan analisis statistik deskriptif melalui verifikasi data dan pemberian skor dan atatistik inferensial Uji F Linieritas dan uji t.

\section{Hasil Penelitian dan Pembahasan}

Analisis kebutuhan guru untuk peningkatan kompetensi menerapkan creative art dalam pembelajaran dan pengentasan masalah siswa dilakukan setelah sosialisasi tentang psikologi neurosain di dalam pembelajaran. Materi ini dipilih karena neurosain merupakan satu teori yang digunakan menjadi dasar dalam creative art. Asesmen terhadap Neurosain dilakukan dengan menggunakan pola BMB3 (Berpikir, merasa, bersikap, bertindak dan bertanggungjawab). Hasil yang diperoleh: 1) peserta berpikir tentang sesuatu yang baru yang di dapatnya di dalam pelatihan seperti konsep neurosain, adanya dinamika otak triun yaitu sistem satu, sistem dua dan sistem tiga dalam pemrosesan informasi. Sistem satu fokus pada 
fungsi kordinasi sensori motor dan gerak refleks. Sistem dua fokus pada fungsi perasaan dan sistem tiga fokus pada fungsi inteligensi. Proses pembelajaran perlu memperhatikan hal ini sehingga guru perlu mewaspadai pelaksanaan pembelajaran sejak awal pada saat merancang pembelajaran (sikap).

Para peserta merasa senang dan bersemangat dengan pengetahuan baru ini (perasaan). Ketika melakukan bermain peran tentang cara yang baik dan cara yang kurang baik dalam memberi respon siswa, para guru merasakan perlunya guru memperhatikan tindakannya (bertindak). Sebagai bentuk tanggungjawabnya guru perlu memikirkan dan melaksanakan pembelajaran sesuai dengan yang seharusnya.

Hasil diskusi dengan guru menunjukkan bahwa ketika melaksanakan pembelajaran guru perlu menggunakan neurosain dalam pembelajaran. Sedangkan untuk pelaksanaannya diperlukan kompetensi dalam menerapkan otak triun dalam pembelajaran dan rancangan stimulasi multi kecerdasan serta rancangan pembelajaran yang menyenangkan. Hasil asesmen menunjukkan bahwa sebagian besar guru memerlukan latihan dalam menerapkan neurosain dalam pembelajaran. Pembelajaran dilaksanakan dalam model creative art play untuk membuat pembelajaran efektif menyenangkan. Demikian juga menggunakan model ini dalam mengentaskan masalah siswa sangat diperlukan guru.

Hasil supervisi terhadap aktivitas guru kelas menunjukkan bahwa rancangan pembelajaran yang disusun guru mengakomodasi aktivitas visualisasi kreatif, menggambar, bercerita, drama, musik dan movement, clay dan pasir. Semua aktivitas ini telah dapat membantu perkembangan proses berpikir siswa, pengembangan moral dan spiritual, membina hubungan sosial, pengalaman estetis, kemampuan berkomunikasi, pengembangan fisik dan motorik serta pengendalian emosi secara terpadu. Secara umum program penguatan kemampuan guru ini berhasil dengan baik. Guru sudah mampu menyusun rancangan kegiatan menggunakan Creative art dengan baik sekali. Pelaksanaan Visualisasi kreatif, bercerita dan drama berkembang baik sekali sedangkan dalam melaksanakan kegiatan menggambar, clay, pasir, puppet, movement, musik berkembang dengan baik. Sedangkan penguatan kemampuan di bidangan pengentasan masalah baik. Hasil kegiatan ini dapat dilihat pada Gambar 1 .

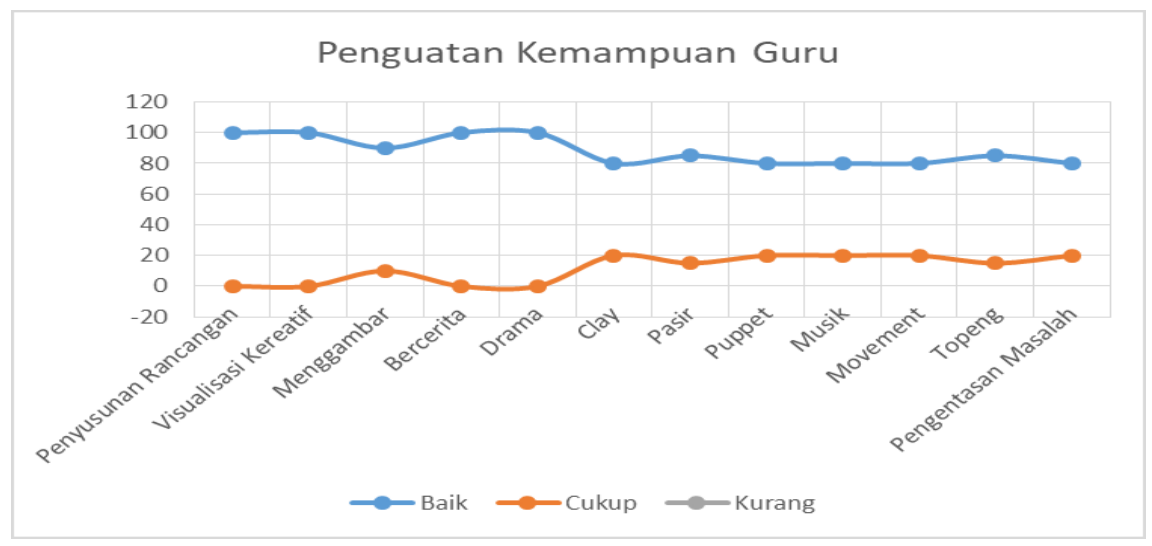

Gambar 1. Penguatan Kemampuan Guru

Sesuaikan dengan kegiatan supervisi pendampingan terhadap guru dalam melaksanakan kegiatan creative art play dan pengentasan masalah ditemukan bahwa terjadi penurunan masalah yang beresiko pada siswa sehingga siswa dapat menghadapi masalah. Hal tersebut dapat ditunjukkan dalam Gambar 2. 


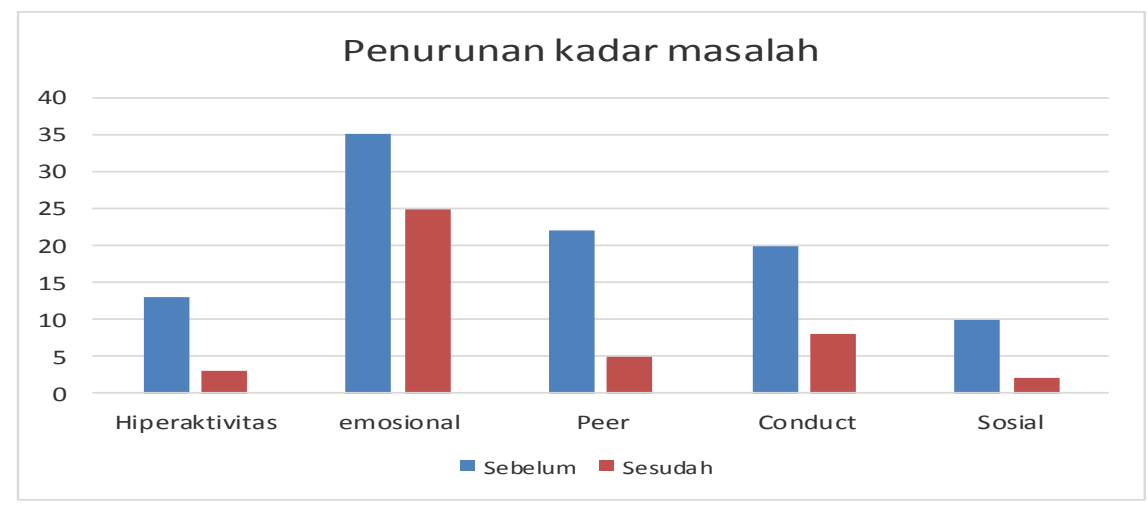

Gambar 2. Penurunan Masalah yang Beresiko

Model yang telah didesain dengan berbasis pada prinsip-prinsip supervisi pendampingan dapat menjamin keberlangsungan dan memandirikan sesuai pendapat (Milfayetty, 2014) ternyata berhasil diterapkan pada kegiatan ini. Pelaksanaan pendampingan yang dilakukan komprehensif dengan melibatkan kepala sekolah, berhasil meningkatkan kompetensi guru-guru. Program pembinaan yang telah dirancang bersama dan implementasikan dapat dievaluasi bersama-sama. Keberlangsungan program telah dijamin dengan monitoring dan evaluasi yang transparan dan terbuka sehingga kepala sekolah dan guru-guru dapat menjalankannya sendiri tugasnya berdasarkan rambu-rambu yang sudah disepakati bersama.

Pelaksanaan penelitian yang dilakukan komprehensif dengan melibatkan kepala sekolah, berhasil meningkatkan kompetensi guru-guru yang menangani Anak Berkebutuhan Khusus (ABK). Sebagaimana hasil penelitian McCormick, Noonan, Ogata, \& Heck (2001) menunjukkan bahwa walaupun telah menunjukkan kolaborasi pengetahuan dan keterampilan para guru. Namun, guru masih memerlukan pelatihan dan praktik dalam bekerja, berkomunikasi dan berkolaborasi dengan pihak lain. Oleh karena itu, hasil penelitian ini memerlukan tindak lanjut, yaitu adanya pelatihan dan praktik dalam bekerja, berkomunikasi dan berkolaborasi dengan pihak lain seperti orang tua siswa dan anggota masyarakat yang terkait dengan pendidikan bagi anak berkebutuhan pendidikan khusus. Sehingga akan tercipta pembelajaran kolaboratif sebagai pendekatan dalam pendidikan pro-aktif yang mana guru umum dan guru khusus serta penyelenggara layanan terkait, menciptakan kegiatan bersama yang terkoordinasi untuk bersama-sama melakukan akses, rencana pembelajaran dan evaluasi akademik serta perilaku terhadap kelompok siswa yang heterogen (Bauwens, Hourcade, \& Friend, 1989).

Program pembinaan yang telah dirancang bersama dan implementasikan dapat dievaluasi bersama-sama. Keberlangsungan program telah dijamin dengan monitoring dan evaluasi yang transparan dan terbuka sehingga kepala sekolah dan guru-guru dapat menjalankannya sendiri tugasnya berdasarkan rambu-rambu yang sudah disepakati bersama. Selanjutnya perlu diuji kelayakan model layanan pendidikan creative art play therapy, dan kemudian dilakukan analisis terhadap respon guru dan orang tua terhadap perkembangan anak berkebutuhan khusus pada PAUD Azura Sejati Inklusif Lhokseumawe.

\section{Kesimpulan}

Hasil penelitian ini menyimpulkan bahwa model layanan pendidikan creative art play therapy efektif digunakan untuk memberikan pelayanan ramah anak berkebutuhan khusus (ABK) dalam menghadapi masalah sosial dan pengendalian diri. Semua proses bermain 
creative art (1) visualisasi kreatif dapat menstimulasi pemahaman dan proses berpikir anak; (2) kegiatan bercerita dapat mengembangkan moral dan spiritual; (3) drama mampu meningkatkan hubungan sosial, boneka tangan dan topeng telah digunakan digunakan untuk melindungi diri; (4) seni untuk mengembangkan kreativitas dan pengalaman estetis; (5) musik untuk berkomunikasi; (6) tari dan gerak untuk mengembangkan fisik motorik.

\section{Saran}

Diharapkan guru dapat memaksimalkan pembelajaran kolaboratif sehingga dapat meningkatkan kompetensi profesional guru sekolah inklusif dalam penanganan anak berkebutuhan khusus.

\section{Daftar Pustaka}

Anamara, Maria Goreti V. (2014). Evaluasi Program Implementasi Standar PAUD. Jurnal Pendidikan Usia Dini. 8 (2): 301-314.

Anzari, Mudhafar et.al. (2018). Hak Memperoleh Pendidikan Inklusif Terhadap Penyandang Disabilitas. Syiah Kuala Law Journal. 2 (1): 57-73.

Bauwen, J., Hourcade, J.J., \& Friend, M. (1989). Cooperative Teaching: A Model for General and Special Education Integration. Remedial and Special Education. 10 (2), 17-22.

Borg, Walter R. dan Meredith Damien Gall. (1979). Educational Research: An Introduction (p. 98). New York: Longman.

Haryono, et.al. (2015). Evaluasi Pendidikan Inklusif Bagi Anak Berkebutuhan Khusus (ABK) di Provinsi Jawa Tengah. Jurnal Penelitian Pendidikan. 32 (2): 119-126.

Kristiana, Ika Febrian. (2015). Sikap Orang Tua dan Guru Terhadap Implementasi Pendidikan Inklusi di PAUD. Jurnal Ilmu Pendidikan. 21 (2), 145-150.

Nissa Tarnoto. (2016). Permasalahan-permasalahan yang dihadapi Sekolah Penyelenggara Pendidikan Inklusif pada Tingkat SD. Humanitas. 13 (1): 50-61.

Mahabbati, Aini. (2014). Kebijakan, Implementasi dan Isu Strategi Pendidikan bagi Individu Berkebutuhan Khusus. Jurnal Pendidikan Islam. 3 (1): 31-46

McCormick, L., Noonan, M,J., Ogata,V., \& Heck, R. (2001). Co-Teacher Relationship and Program Quality: Implication for Preparing Teacher For Inclusive Preschool Settings. Education and training in mental retardation. 36: 119-132.

Milfayetty, Sri. (2017). The Innovative Model of Counselors Collaboration in Alleviating The Student's Charcter. Ponte, 3 (1): 5-11.

Milfayetty, Sri., et. al. 2017. Model Creative Art dalam Bermain Clay untuk Meningkatkan Perkembangan Motorik Halus dan Kemandirian Anak. Proceedings International Psychology, Education Counseling \& Social Work Conference. Medan, Indonesia.

Mudjito, et. al. (2012). Pendidikan Inklusif (p.87). Jakarta: Baduose Media.

Mulyono, Rachmat., et.al. (2017). Pengaruh Intensi, Motivasi, dan Pemahaman Guru terhadap Implementasi Pendidikan Inklusif. Jurnal Pendidikan Usia Dini. 11 (2): 293-307.

Sadioglu, Omur, et. al. (2013). Problems, Expectations, and Suggestions of Elementary Teachers Regarding Inclusion. Educational Sciences: Theory and Practice. 13 (3): 760-765.

Schmidt, S dan Venet, M. (2012). Principals Facing Inclusive Schooling or Integration. Canadian Journal of Education. 35 (1): 217-238.

Smith, J. D. (2006). Inklusi: Sekolah Ramah untuk Semua (p.9). Bandung: Penerbit Nuansa.

Santrock, J. W. 2013. Psikologi Pendidikan (p.67). Jakarta: Salemba Humanika. 
Suparo. (2011). Desain Pembelajaran untuk Guru TK Inklusif. Cakrawala Pendidikan. (3): 388-400.

Rudiyati, Sari. (2013). Peningkatan Kompetensi Guru Sekolah Inklusif dalam Penanganan Anak Berkebutuhan Pendidikan Khusus Melalui Pembelajaran Kolaboratif. Cakrawala Pendidikan. (2): 296-306.

Weiner, Howard M. (2003). Effective Inclusion (Professional Development in Context of the Classroom). Teaching Exceptional Children Journal. 36: 12-18. 